\title{
MISLAV ŽITKO
}

$$
\text { Mišljenje i }
$$

revolucija:

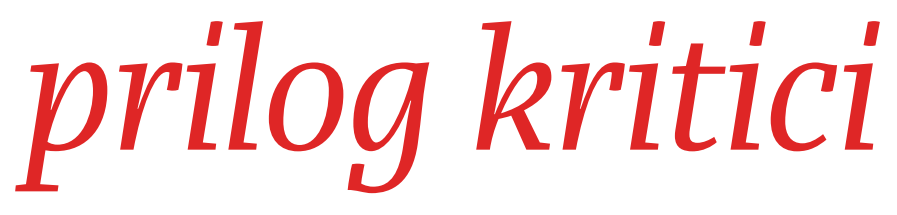

$$
\text { filozofije }
$$

Gaje Petrovića 
sprkos tome što kontroverzna povijest praxis filozofije nipošto nije svodiva na opus jednog člana tog misaonog kolektiva, usredotočenost na teorijski rad Gaje Petrovića može biti opravdana utoliko što se u njemu sabiru problemi i proturječja karakteristični za cjelokupnu grupaciju. Riječ je o zanimljivom kolopletu nerazjašnjenih odnosa između filozofije, revolucije i socijalizma, koji je aktualan još danas u mjeri u kojoj preko analize Petrovićeve teorijske produkcije možemo doći do problema kojima je tradicijski dan status trajnog postava u filozofskim istraživanjima. Dosadašnje bavljenje praxis filozofijom rijetko je napuštalo interpretacijske krajnosti. U jednom slučaju ta je inačica marksističke filozofije reducirana na ideološki supstrat socijalističkog režima čineći ga glasilom Saveza komunista Jugoslavije. Takva je interpretacija, kako pokazuje ovaj tekst, sasvim promašena. Razumljivo je da je praxis filozofija unižena do tog statusa unutar procesa transformacije humanističkih i društvenih disciplina uslijed uspona nacionalističkog diskursa od početka devedesetih naovamo. To ujedno objašnjava drugu interpretacijsku krajnost koja se ogleda u različitim pokušajima da se praxis filozofija predstavi u funkciji nastavka "hrvatske filozofije" drugim sredstvima. Nijedna od spomenutih interpretacija nema minimum teorijske vjerodostojnosti, usprkos tome što gdjekad možemo imati razumijevanja za dobrohotan teorijsko-politički diletantizam drugog interpretacijskog sklopa.

Prve naznake višeslojnog i često proturječnog odnosa praxis grupacije prema, najprije, statusu filozofije unutar akademske podjele rada, a zatim prema pozicioniranju filozofije unutar procesa socijalističke modernizacije, nalazimo u transkriptu razgovora članova zagrebačke i beogradske frakcije grupe praxis pod naslovom "Sloboda i nasilje” (2003) koji je uz pomoć Petra Milata i Tomislava Medaka za objavljivanje priredio Nebojša Popov. Izvan toga, radovi Borislava Mikulića sabrani u knjizi Nauk neznanja (2015a) čine prvi korak prema kritičkoj recepciji praxis filozofije, onkraj dosadašnjih interpretacija koje jedva da su sakrivale instrumentalne motive pod maskom filozofskog žargona. Problem kojemu ćemo se posvetiti u ovom tekstu vezan je uz srž teorijskog rada Gaje Petrovića, odnosno uz onu žarišnu točku u kojoj se susreću filozofija, revolucija i socijalizam.

Na početku možemo reći da je pokušaj re-filozofikacije marksizma kod Gaje Petrovića proizveo distorziju političnosti filozofije zbog koje je nemoguće preskočiti analizu (samo)razumijevanja filozofije u Petrovićevom diskursu. Što se misli pod, na prvi pogled, nejasnom formulacijom distorzije političnosti filozofije? U ambicioznom 
pokušaju sjedinjenja mišljenja i revolucije koji naposljetku propada pod težinom preuzete zadaće, Petrović uvlači filozofiju u specifičan politički projekt izgradnje autentičnog socijalističkog društva uslijed čega filozofija, paradoksalno, izlazi "nevinija i čišća” nego što je nalazimo u tradiciji od Platona do Kanta gdje je pretenzija na status "vrhovnog diskursa", odnosno težnja ka zauzimanju utemeljiteljske uloge u proizvodnji znanja sprečavala otvoreno zagovaranje specifičnih ekonomsko-političkih aranžmana. Prije nego što se dotaknemo razmatanja analitičkog klupka nastalog iz Petrovićeva sintetičkog rada, navest ćemo problemske razine koje se kod njega pojavljuju, veoma često isprepletene do neprepoznatljivosti. O tome da prethodno opisano nastojanje Gaje Petrovića oko objedinjenja filozofije i socijalizma čini sukus njegova rada ne može biti sumnje budući da on to na više mjesta eksplicitno navodi. Primjerice, u broju 5-6 časopisa Praxis iz 1973., godinu dana prije zabrane časopisa, Petrović u tekstu "Filozofija i socijalizam - još jednom" iznosi sljedeću formulaciju: "Nasuprot shvaćanju u kojemu filozofija kao pokušaj mišljenja cjeline svijeta nije i ne može biti ni u kakvom posebnom odnosu prema socijalizmu kao društveno-političkom poretku, pokretu ili teoriji, shvaćanju koje je veoma prošireno kako kod filozofa, tako i kod socijalista, zastupao sam tezu o neodvojivoj povezanosti filozofije i socijalizma, tezu da nema realizacije filozofije bez ostvarenja socijalizma." (PETROvić, 1973: 610)

Ono što je, prema tome, u Petrovićevom djelu isprepleteno jesu filozofija i socijalizam, zajedno sa svojim povijestima i križanjima s drugim intelektualnim i političkim pothvatima koja su ih veoma često odvodila u sasvim različitim smjerovima. Problem statusa filozofije u socijalizmu je, začudo, na relevantan način formulirao Jürgen Habermas u istom broju časopisa Praxis iz 1973. godine. Tamo Habermas, uočavajući da je filozofija kao proizvod građanskog svijeta oduvijek bila osporavana od strane marksista, nudi polaznu točku analize kroz razmatranje onih proizvodnih aspekata filozofije koji ostaju nakon što je kritika ideologije izvršena. Habermas piše:

"Socijalizam ne potvrđuje tek samorazaranje građanskog svijeta; on treba biti ujedno i njegov legitimni nasljednik koji će očuvati, osloboditi i dalje razvijati proizvodne snage građanskog svijeta." (HABERMAS, 1973: 601) 
S obzirom na različite kritičke pozicije prema kapitalizmu i građanskom svijetu, koje su se razvile unutar marksističkih i nemarksističkih teorija, izuzetno je važno koji će se elementi građanskog svijeta računati pod proizvodni povijesni potencijal (IBID.). Kod samog Marxa, dakako, problem polja kulturne proizvodnje, kojemu pripada filozofija, nije nedvosmisleno riješen. S jedne strane, Marxova je kritika ideologije usmjerena na one oblike građanskog polja kulturne proizvodnje koji stoje u neposrednoj službi skrivanja i maskiranja društvenih antagonizma unutar klasne strukture. U tom se smislu kritika političke ekonomije pojavljuje kao nastavak na prethodno poduzetu kritiku religije. U kritici ideologije marksizam se suočava s neprijateljem s kojim nema prosvjetiteljskog dijaloga, odnosno riječ je o točki na kojoj, kako primjećuje Peter Sloterdijk (1995), prosvjetiteljski razgovor s ciljem dosezanja boljeg uvida na temelju prihvaćanja racionalnih argumenata biva preobražen u proceduru raskrinkavanja. Marxov odnos prema filozofiji u tom je pogledu bio dovoljno ambivalentan da ostavlja otvorenim pitanje do koje mjere treba filozofiju, koja je proizašla iz građanskog svijeta, uzeti kao proizvodnu snagu neophodnu za izgradnju socijalizma. Tu se otvara prvi problem za Petrovićevu poziciju koja, osobito u prvoj fazi razrade filozofije prakse, sadrži često ponavljanu jaku tezu o međusobnoj uvjetovanosti filozofije i socijalizma. Petrović u tom kontekstu, uglavnom bez razrađenih distinkcija, preuzima cijeli paket filozofije ne vodeći računa o njegovom porijeklu. Taj je paket bio predmet analitičke demontaže kod samog Marxa na nebrojeno mnogo mjesta od kojih je svakako najupečatljiviji obračun s Hegelom putem kritike mladohegelijanaca u Njemačkoj ideologiji:

"Daleko od toga da istražuje svoje opće-filozofske pretpostavke, sva njena pitanja izrasla su na tlu jednog određenog filozofskog sistema i to - Hegelova. Ne samo u njenim odgovorima nego je i u samim njenim pitanjima ležala mistifikacija... Nijednom od ovih filozofa nije uopće palo na napamet da postavi pitanje o vezi njemačke filozofije s njemačkom stvarnošću, o vezi njihove kritike s njihovom materijalnom okolinom.”

Marxova intervencija u Njemačkoj ideologiji važna je jer postavlja okvir za materijalističku kritiku filozofskog idealizma, te istovremeno utemeljuje poziciju kritičara ideologije koji dolazi u sukob s akademskom ili profesorskom filozofijom što posljedično izaziva potpunu promjenu terena. Onkraj onoga što se već tada iskristaliziralo 
kao akademska filozofija Robert Pippin precizira sadržaj posthegelovskih strujanja koja bacaju sumnju na temeljna potraživanja buržoaske filozofije utoliko što dovode u pitanje racionalnu, autonomnu, slobodnu i refleksivnu subjektivnost na temelju koje se legitimira sam buržoaski oblik života (PIPPIN, 2006: 3). Buržoaska je subjektivnost, nastavlja Pippin, s Hegelom prerasla svoj kartezijanski kostim prije svega $u$ inzistiranju da je dosegnuta normativna dimenzija buržoaske filozofije neodvojiva od složenih uvjeta društvene međuovisnosti. Drugim riječima, filozofski sadržaj umnosti i slobode kojim se opisuje buržoaska subjektivnost neodvojiv je od historijskih i društvenih uvjeta svoga nastanka (IBID., 12). Pokušaj refilozofikacije marksizma kod Petrovića ne poznaje propitivanje promjene forme filozofije što mu omogućuje oslanjanje na esencijalističku, odnosno internu povijest filozofije u kojoj se filozofija jednostavno pokazuje kao "misao bivstvovanja" ili "misao koja misli bivstvovanje". ${ }^{01}$ Nediferencirano preuzimanje filozofije, odnosno nereflektirani govor iz mjesta filozofije u cilju refilozofikacije marksizma kod Petrovića proizvodi slične učinke poput onih koje Mikulić bilježi u slučaju Milana Kangrge:

"Striktno kultiviranje kritike birokratskog aparata socijalističke države u praxisu uz zanemarivanje ili nedovoljne analize građanskih oblika proizvodnje ideologije u socijalizmu poput kulture, morala ili prava, s izuzetkom kritike nacionalizma, može se čitati i kao čuvanje ideološke nevinosti građanskog društva općenito naspram države i vlasti otuđene od partije. Osobito tipičan primjer za takvu vrstu podvojenosti unutar grupacije praxis predstavlja notorno Kangrgino odbacivanje liberalne filozofije politike, prava i morala uz paralelno propagiranje 'povijesnog deficita na ovim prostorima' i zagovaranje povratka na temeljne tekovine građanske civilizacije I9. stoljeća.” (MIKULIĆ, 2015 B: OVDJE)

Kod Petrovića doduše nije u prvom redu riječ o "čuvanju ideološke nevinosti građanskog društva”, ali jest o preuzimanju normativnih elemenata buržoaske filozofije bez jasnog historijskog i društvenog smještanja, dakle bez jasne ideje odakle ta predodžba slobodne, neovisne, samo-

\section{Refilozofikacija} marksizma nije posebnost praksisovaca u jugoslavenskom intelektualnom polju, dapače istu formulaciju i intenciju možemo naći kod institucionalno i intelektualno odvojenih autora poput Vanje Sutlića: "Tako, čini se, stojimo pred interpretativnom dilemom s obzirom na Marxovu misao: Ako ona nije više filozofija, onda zastupa znanosti, te interpretativno valja napustiti metafizički balast kojim je opterećuju; ako pak vodimo računa o njezinom podrijetlu, zamašnosti i specifičnoj razlici spram faktičkih znanosti, valja nam Marxa refilozoficirati" (Sutlić 1974: ii). 
svjesne subjektivnosti dolazi. U nastavku ćemo pokazati da Petrović, poput Kangrge, kritizira ideološke forme građanskog društva dok se istovremeno oslanja na formulaciju filozofije prakse $u$ čijem se središtu ne nalazi ništa drugo doli ona ista slobodna, neovisna i samosvjesna subjektivnost potekla iz buržoaske filozofije. Budući da za Petrovića filozofija nema povijesnu dimenziju vrijednu istraživanja, činjenica da je filozofija njemačkog klasičnog idealizma dio ukupnog polja kulturne proizvodnje ne dolazi do potrebnog izražaja. Otud paradoksalni ishod u kojemu se filozofija i socijalizam povezuju na temelju tropa i figura buržoaske filozofije, bez kriterija odabira koji ionako može biti formuliran, kako je naglasio Habermas, samo na temelju kritike ideologije. Dakle, umjesto razmatranja statusa filozofskog diskursa kroz za marksizam obvezujuću prizmu kritike ideologije, Petrović nudi obrnuti put koji se očituje u postepenom zamjenjivanju filozofije prakse mišljenjem revolucije. Riječ je o daljnjem postupku refilozofikacije temeljenom na približavanju Heideggerovoj fundamentalnoj ontologiji. Prethodne nedorečenosti vezane uz status filozofije u polju kulturne proizvodnje sada su dodatno usložene budući da Heideggerova filozofija predstavlja konzervativni odgovor na proturječnosti građanske civilizacije, sasvim različit od marksističke kritike kakvu primjerice nalazimo kod Frankfurtske škole ili drugih inačica zapadnog marksizma. Razumijevanje Petrovićevog okreta ka Heideggeru vezano je uz diskurs autentičnosti koji je sagrađen oko analitike otuđenja.

\section{Analitika otuđenja i kontinuitet Marxovog mišljenja}

Pojam otuđenja u Petrovićevoj filozofiji bez sumnje zauzima središnje mjesto koje autoru omogućuje stvaranje jedinstvene povijesti marksizma s jedne, te kritiku birokratskog socijalizma, s druge strane. Uz podvlačenje onoga što je ranije rečeno u vezi nediferenciranog prisvajanja filozofije u funkciji stvaranja saveza s marksističkom teorijom i (idealnim) socijalističkim poretkom, treba istaknuti da za Petrovića nije sporno kako filozofija u tom savezu nedvosmisleno zadržava primat nad marksističkom teorijom:

"Međutim, ako se filozofija prakse ne može utrpati u uske okvire historijskog materijalizma, ona je sama dovoljno široka da kao svoj moment obuhvati i historijski materijalizam - kao jednu posebnu teoriju. U filozofiji prakse čovjek se shvaća kao slobodno stvaralačko biće, koje svojom djelatnošću oblikuje sama sebe i svoj svijet. No upravo kao slobodno biće on se može otuđiti od sama sebe, postati otuđeno, neslobodno biće, ekonomska životinja. Upravo zato što 
se čovjek samootuđuje, teorija historijskog materijalizma ima svoje opravdanje i relativnu vrijednost kao objašnjenje i kritika samootuđenog društva i čovjeka. Međutim, istrgnut iz cjeline filozofije prakse i osamostaljen historijski materijalizam mogao bi samo opisati mehanizam ekonomske determinacije i eksploatacije u klasnom društvu, a odlučnu tezu da su to društvo i čovjek samootuđeni, neljudski, ne bi čak mogao ni izreći.” (PETROVIĆ, 1986 B: 19)

S obzirom na pretpostavljeni odnos filozofije i marksizma ne treba čuditi što je rad na ovjeravanju filozofskog statusa Karla Marxa i marksizma za Petrovića bio stalni zadatak kojemu se neprestano vraćao. Primjerice, u tekstovima "Mladi i stari Marx" i "Kontinuitet Marxove misli” Petrović poduzima za njega karakteristično istraživanje o “pravom Marxu”. Na početku prvog spisa on će kazati:

"Pravi Marx - to je ono čime je Marx zadužio historiju. Prava Marxova filozofija - to je Marxov doprinos razvoju filozofske misli.” (PETROVIĆ, 1986 A: 43)

Budući da Petrović, kako smo već naglasili, ni u jednom trenutku ne odustaje od razrade utemeljiteljskog mandata filozofije, potvrđivanje i dokazivanje Marxovog filozofskog statusa i otkrivanje biti marksističke filozofije bile su zadaće od prvoklasne važnosti. Već se u zbirci eseja i članaka iz ig65. Petrović u više navrata dotiče tih pitanja. Ponajprije, $\mathrm{u}$ tekstu "Marx kao filozof" kritizira one koji tvrde da Marx nije filozof, odnosno da postoji postepeni prijenos Marxovog istraživačkog interesa iz domene filozofije na domenu političke ekonomije ili društvenih znanosti. Nadalje, u tekstu "Marxova filozofija” Petrović nastavlja razmatranje o biti Marxove filozofije, te uvodi određenje Marxove filozofije kao filozofije čina ili prakse:

"Ako jednu filozofiju bitno karakteriziramo kao filozofiju čina (djela, prakse), to mora značiti da čin (djelo, praksa) proistječe iz biti njenog teorijskog sadržaja, da je prijelaz od teorije ka praksi njena bitna ‘teza'. Prema tome, ako karakteriziramo Marxovu filozofiju kao filozofiju čina, moramo objasniti koje su to njene bitne teze zbog kojih ona ne može ostati čista teorija nego mora prerasti u djelo revolucionarnog mijenjanja svijeta.” (PETROvić, 1965: 73)

U spomenutim se tekstovima, čiji naslovi otkrivaju Petrovićevu intenciju, može vidjeti temeljno kretanje njegovog mišljenja. U prvom 
koraku marksizam se mora supsumirati pod filozofiju. To je potrebno kao jamstvo stvaranja autentičnog marksizma u opreci spram mogućih devijantnih ili vulgarnih inačica koje mogu nastupiti kao opozicija filozofiji prakse u intelektualnom polju. Filozofija od marksizma, u drugom koraku, uzima revoluciju bez koje filozofija ostaje na razini interpretacije ili sistematizacije svijeta, lišena fundamentalno proizvodnog karaktera. Petrović će, dakako, pokušati dati daljnja objašnjenja u svrhu afirmacije dogovorenog braka filozofije i marksizma, osobito u veoma instruktivnom tekstu "Filozofski pojam revolucije" iz i973. godine. Na početku rasprave Petrović kroz deset točaka objašnjava sadržaj pojma revolucije, navodeći kako revolucija nije samo osvajanje vlasti od strane progresivne klase, nego radikalna promjena društva koja se ne može dogoditi bez stvaranja novog čovjeka (PETROVIĆ, 1986 B: 76). Iako razrada pojma revolucije kreće od sasvim jednostavnih napomena u prvih nekoliko točaka, uglavnom usmjerenih na određenje kvalitativne razlike između socijalističke revolucije i drugih revolucija, odnosno prevrata u povijesti, do zaključnih točaka devet i deset Petrovićeve eksplikacije, revolucija prestaje biti društveni fenomen uopće, te postaje "bit bivstvovanja”. U desetoj se točki navodi sljedeće:

"Samo filozofski pojam revolucije može primjereno misliti revoluciju, i to samo pod uslovom da ne ostane samo filozofski ni samo pojam. Samo filozofija, koja se sama ukida, koja se od mišljenja revolucije uzdiže k mišljenju kao revoluciji, može sudjelovati u revoluciji i sudjelujući misliti revoluciju.” (IBID., 77)

Ostatak teksta posvećen je obrazloženju teza u prepoznatljivom argumentacijskom dvokoraku. U prvom koraku, revolucija znači radikalnu promjenu društva, a radikalna promjena društva ne može se ostvariti bez radikalne promjene čovjeka. Pitanje o čovjeku povezano je s pitanjem o smislu bivstovanja, što znači da se revolucija ne može misliti na antropološkoj, sociološkoj i drugim razinama, već samo na (specifično pojmljenoj) filozofskoj. U drugom se koraku navodi kako je bit ljudskog bivstovanja praksa, odnosno čovjek je kao biće prakse slobodno i stvaralačko biće. Shodno tome može se lako predvidjeti sljedeći zaključni navod:

"Kao biće prakse čovjek je slobodno i stvaralačko biće, kao takvo on je i biće revolucije. Revolucija nije neka posebna pojava u povijesti, nego najkoncentriranija forma ljudskog kolektivnog stvaralaštva, forma u kojoj najjasnije dolazi do izražaja stvaralačka priroda čovjeka.” (IBID., 87) 
Iako Petrović načelno govori kako se socijalistička revolucija, jedina autentična revolucija, može misliti samo kao "nikad ne završavajući proces” (IBID. 88), konceptualno je riječ o strogo zatvorenom postupku s obzirom da mišljenje, praksa i revolucija upućuju jedno na drugo, stvarajući tako poročni krug pseudo-argumentacije. To nas dovodi do normativne dimenzije projekta refilozofikacije marksizma, odnosno točke na kojoj se analiza Petrovićeve filozofije prakse okreće od teksta ka ekonomsko-političkom režimu unutar kojeg je Petrović djelovao.

\section{Bespoštedna kritika svega postojećega, ponajprije Staljina}

Prethodno je naznačeno kako kod Petrovića djeluje "druga scena” na kojoj se pokazuje političnost filozofije u mjeri u kojoj filozofija mora nadrasti svoju interpretacijsku funkciju i pretvoriti filozofiju prakse, dakle fundamentalnu refleksiju o praksi, u nešto više: revolucionarno mijenjanje svijeta. Daleko od toga da se političnost filozofije pojavljuje u funkciji kritike skolastičkog uma, dakle u preispitivanju samorazumijevanja "profesorske" filozofije kroz kritiku "interne" povijesti filozofije i historizaciju filozofskog kanona, ona kod Petrovića ima sasvim specifičnu namjenu u kojoj se gotovo iscrpljuje: naime, kritiku staljinizma. Na konceptualnoj razini staljinizam predstavlja moment negativne konstitucije filozofije prakse s obzirom da se tek na njegovoj pozadini može razabrati pozitivni, to jest stvaralački potencijal filozofskog mišljenja i revolucionarne prakse. Staljinizam se u Petrovićevom diskursu ne pojavljuje, barem ne primarno, kao historijski fenomen, već prije kao opredmećenje neautentične egzistencije ili otuđenja. Filozofija prakse gradi svoju normativnost u gotovo ekskluzivnoj usredotočenosti na staljinizam i njegove suvremene ekstenzije. Staljinizam predstavlja ishodišnu točku u mjeri u kojoj omogućuje da se neautentična, otuđena egzistencija imenuje i prokaže, te tako dopusti filozofiji prakse pronalazak biti čovjeka putem afirmacije revolucionarnog stvaralaštva. Važno je napomenuti da sama kritika staljinizma ne predstavlja posebnost praksisovaca, odnosno Gaje Petrovića. Štoviše, kritičke opservacije na temu Staljina i staljinizma predstavljaju opće sadržajno obilježje jugoslavenskog intelektualnog polja. Nalazimo ih u naglašenom obliku u intelektualno i politički oštro suprotstavljenim publikacijama poput Nove klase Milovana Đilasa, s jedne i Pravcima razvoja političkog sistema socijalističkog samoupravljanja Edvarda Kardelja, s druge strane. Kritika staljinizma u tom je pogledu svakako začudni fenomen po svojoj proširenosti, te u slučaju praksisovaca ne predstavlja točku razdvajanja od onodobnog 
intelektualnog mainstreama, već prije točku koja signalizira lojalnost jugoslavenskoj inačici socijalizma.

U filozofiji Gaje Petrovića kritika staljinizma naizmjence se koristi za obračun s drugim marksističkim frakcijama i za konceptualizaciju, odnosno filozofsko fundiranje pojma otuđenja. Prva točka obračuna sa staljinizmom u marksizmu je, dakako, sam Marx. Prethodno smo vidjeli da je Marx u Petrovićevoj interpretaciji eminentno filozof, a ne sociolog, antropolog, politički ekonomist i slično. Klasifikacija izvedena na temelju postojeće intelektualne podjele rada dobiva svoj puni izraz u kritici staljinizma jer ona omogućuje Petroviću da fiksira Marxov intelektualni habitus kroz tezu o kontinuitetu Marxove misli. Naime, "kod 'marksista-staljinista' teorija o mladom i starom Marxu konkretizira se u tezu da je zreli Marx, trezveni naučenjak-ekonomist, prevladao i učinio neaktualnim mladog Marxa, apstraktnog filozofazanesenjaka." (PETrović, 1986 A: 47) Petrović ne zastupa tezu da je mladi Marx nadmoćan starom, nego da u procesu Marxovog razvoja nije bilo zaokretâ koji bi značili potpun prekid sa ranijim koncepcijama (IBID., 46), i u tome uvođenje Ekonomsko-filozofskih rukopisa iz I844. igra važnu ulogu jer u njima on pronalazi većinu formulacija potrebnih za izgradnju pojmovnog kompleksa filozofija-marksizam-socijalizam. Drugačije rečeno, Petrovićeva filozofija u razdoblju nakon raskida sa Staljinom I948. i proliferacije različitih oblika kritike staljinizma u jugoslavenskom intelektualnom polju, gradi filozofiju prakse oko dviju osi: najprije oko pozitivnog uslovljavanja filozofije i marksizma, a zatim oko negativnog ili isključujućeg uslovljavanja autentičnog bivstovanja i staljinizma. U tekstu “Kontinuitet Marxove misli”, Petrović to sabire na sljedeći način:

"Osnovna je ideja Marxovih Ekonomsko-filozofskih rukopisa da je čovjek slobodno stvaralačko biće prakse koje je u suvremenom svijetu otuđeno od svoje ljudske suštine, ali da radikalan oblik koji poprima čovjekovo samootuđenje u suvremenom društvu stvara realne uvjete za borbu protiv samootuđenja, za ostvarenje socijalizma kao slobodne razotuđene zajednice slobodnih ljudi.” (IBID., 55)

Traženje oslonca u Ekonomsko-filozofskim rukopisima predstavlja razumljiv izbor u kontekstu refilozofikacije marksizma. Rukopisi stavljaju Marxa u društvo Hegela, koji je prema Petroviću prvi filozofski razradio pojam otuđenja (PETROVIĆ, 1986 A: 154), i Martina Heideggera čija se analiza bezličnog "se”, tj. "nepravog bivstovanja 
u prosječnoj svakodnevici” (PETROvić, 1986 B: 29) predstavlja u paralelizmu s Marxovim poimanjem otuđenja. Petrović propušta uočiti činjenicu da se Heideggerova razrada otuđenja pojavljuje u svjetlu "konzervativne revolucije" u kritičnom periodu raspada vajmarske kulture i posljedičnog uspona nacionalsocijalizma (USP. BOURDIEU, 1996; GAY, 1999). U svakom slučaju, uklapanje alijenacije ili otuđenja u internu povijest filozofije stvara tendenciju da se pojam mjestimice upotrebljava transhistorijski, bez obraćanja pažnje na konkretne društveno-ekonomske uvjete unutar kojih se otuđenje kao fenomen pojavljuje. Interpretacijska prekrajanja Marxove teorije koja su potrebna da bi se održao transhistorijski pojam otuđenja vode mjestimice Petrovića na puteve posve proizvoljnog prikazivanja Marxovih teza, kako to pokazuje odlomak iz spomenutog "Filozofskog pojma revolucije”:

"Prema Karlu Marxu, dosadašnja historija bila je samo prethistorija u kojoj je čovjek bio otuđen od svoje biti. To ne znači da on posjeduje neku danu, čvrstu bit. Čovjek je otuđen od svoje biti - to znači da on ne realizira svoje povijesno stvorene mogućnosti. Čovjek, naprotiv, nije samootuđen ukoliko on svoje stvaralačke mogućnosti istovremeno ostvaruje i proširuje, ukoliko u društvenom životu djeluje kao biće revolucije.” (PETROVIć, 1986 B: 87)

Problem koji se ogleda u ovom odlomku (ali i na mnogim drugim mjestima) svodi se na sljedeće: Petrović želi zadržati jaki normativni pojam otuđenja, ali da bi to učinio, potrebno je fiksirati značenje autentičnosti koje stoji nasuprot otuđenju. Petrović je zasigurno bio svjestan kako je transhistorijska stabilizacija značenja autentičnosti "nemoguća misija”, te umjesto toga nudi upadljivo nespecificiranu formulaciju “povijesno stvorene mogućnosti” koje se ostvaruju ako čovjek djeluje kao biće revolucije. Nekoliko redaka kasnije čitamo kako je revolucija bit bivstvovanja (IBID., 88), što u sažetoj verziji znači da čovjek ostvaruje svoju bit, odnosno izbjegava otuđenu egzistenciju ako djeluje revolucionarno, i djeluje revolucionarno ako ostvaruje svoju bit, odnosno "realizira povijesno stvorene mogućnosti”. Sažimajući prethodno rečeno, normativni pojam otuđenja uslovljen je kritikom staljinizma, ali u negativnom smislu - staljinizam predstavlja devijaciju socijalizma koja nam govori kako ne bi trebalo biti. Međutim, normativnost marksističke filozofije ne može u potpunosti ovisiti o kritici staljinizma, budući da ona, makar bila potpuna i ispravna, ne nudi pozitivan sadržaj kojega normativnost definicijski traži. Taj 
upadljivi manjak Petrović rješava uveličavanjem staljinističkog fenomena do neodrživih razmjera i, još dubioznije, zagovaranjem provizorne ontologije "autentičnog” pod konceptualno neuhvatljivom sintagmom "mišljenje revolucije”.

Nije tajna da se jedna od posljedica proširivanja kritike staljinizma u kontekstu refilozofikacije marksizma ogleda u "fascinaciji predmetom svoje kritike, svijetom otuđenog birokratskog aparata nad socijalističkim društvom” (MIKULIĆ, OvDJE: 106). Štoviše, možemo slijediti i rekonstruirati teorijski vokabular kojeg Petrović razrađuje najprije za potrebe obračuna s teorijskim ostacima staljinizma, a zatim za analizu "birokratskog socijalizma”. Vraćajući se na odnos argumentacijske jezgre Petrovićeve filozofije i ekonomsko-političkog poretka, postupno zatvaranje unutar disciplinarnih granica proizvelo je kod Petrovića, na prvi pogled, paradoksalni učinak sve izraženijeg teorijskog zastupanja filozofije prakse, odnosno njezine zaoštrenije verzije - mišljenja revolucije u cilju izgradnje "autentičnog socijalizma”, kako se stvarno postojeći jugoslavenski socijalizam razgrađivao prema punokrvnom tržišnom društvu. Kritika staljinizma zajedno sa svojom ekstenzijom u obliku kritike birokratskog socijalizma dosegla je moment saturacije u političkom smislu krajem šezdesetih godina kada je jugoslavenski socijalizam nepovratno krenuo putem liberalizacije ekonomskih odnosa i političke decentralizacije zaključno s donošenjem novog Ustava 1974. Praxis filozofija nikad nije uspjela povezati kritiku nacionalizma s procesom decentralizacije i institucionalne izgradnje političke autonomije na republičkim razinama. Prema našem sudu, riječ je o ograničenosti koja ne proizlazi iz ograničenog dosega kritičkog humanizma, koji su u javnom diskursu njegovali mnogi praksisovci, nego iz fundamentalnih nedostataka praxis filozofije od kojih ćemo istaknuti dva osobito vidljiva kod Gaje Petrovića. Prvi se odnosi na nedostatak kritike kapitalizma i pripadajućih ideoloških oblika. Može se činiti neobičnim što jedna marksistička škola propušta kritički analizirati kapitalizam, no treba se sjetiti da praxis općenito i Petrović posebno grade projekt refilozofikacije marksizma na osi pozitivnog uslovljavanja filozofije i marksizma s jedne, te negativnog uslovljavanja autentičnog bivstvovanja i staljinizma, s druge strane. Kapitalizam se pojavljuje, u tom pogledu, tek kao jedna epizoda u povijesti otuđenja, odnosno birokratski socijalizam zauzima, u mjeri u kojoj je riječ o "unutrašnjoj” devijaciji socijalizma, mjesto privilegiranog predmeta analize. Na isti način na koji su Edvard Kardelj i drugi 
organski intelektualci samoupravljanja držali da je nacionalno pitanje riješeno, Petrović i drugi praksisovci nisu prepoznali kapitalizam i problematiku tržišnih odnosa dostatno da ih podvrgnu kritičkoj analizi bez supsumpcije pod zamišljenu opću povijest otuđenja. Nadalje, ista opisana teorijska matrica, koja je analizu kapitalizma preobrazila u sekundarno pitanje, onemogućavala je, na drugi način, dalekosežniju kritiku jugoslavenskog socijalizma. Birokratski je aspekt socijalizma, u mjeri u kojoj je doista bio prisutan u jugoslavenskoj ekonomskopolitičkoj povijesti, predstavljao ipak samo jedan aspekt tog poretka. Drugi nosivi aspekti jugoslavenskog socijalizma bili su dostupni kritičkom aparatu pod vidom analize specifičnih institucionalnih oblika i praksi. Upravo je taj dio redovito izostajao u Petrovićevim razmatranjima koja su skakala od filozofske dijagnoze alijenacije do zagovaranja autentičnog socijalizma bez primjerene međupoveznice, kakvu primjerice nudi Milovan Đilas u Novoj klasi. Naravno, Petrović je morao čuvati krhku poziciju lijeve kritike jugoslavenskog socijalizma u akademskom polju, dok je Đilas imao privilegiju da kao partijski otpadnik razotkriva tajne režima zapadnim medijima, no time se teško može objasniti grandiozno i posve dislocirano shvaćanje birokracije kakvo, primjerice, nalazimo u članku "Birokratski socijalizam" iz I97I. godine:

"Birokracija je činovništvo koje u odlučnim pitanjima društvenog života donosi konačnu odluku i ne poznaje nikakve više instance iznad sebe. Time naravno još nije ništa rečeno o konkretnoj formi birokratske vladavine. Birokracija se može služiti direktno terorističkim metodama, ali ona može i 'igrati demokraciju'. Gdje staljinistička birokracija drži u svojim rukama ne samo armiju, sudstvo i policiju nego i sva sredstva masovne komunikacije, objavljujući preko njih samo svoju vlastitu birokratsku istinu. Birokracija koja čvrsto drži vlast u svojim rukama može čak organizirati antibirokratske kampanje, a samu sebe proglasiti prvoborcem socijalizma i samoupravljanja.” (PETROVIĆ 1986 B: 197)

Čak ni u razdoblju konsolidacije staljinizma između i945. i 1953. problem Sovjetskog Saveza nije ležao u samoj birokraciji koje ne poznaje više instance, nego upravo u višim instancama (zaključno, dakako, sa Staljinom) koje su instrumentalizirale državni aparat. Jugoslavenski problem nakon raskida sa sovjetskim modelom, s druge strane, nije bio primarno vezan za centraliziranu birokratsku strukturu koja uzurpira ekonomsku i političku moć, nego, suprotno, 
za decentralizaciju odlučivanja koja je u posljednjoj fazi od federalnih tijela pretvarala u nominalna tijela upravljanja, bez stvarnog utjecaja na političku dinamiku u pojedinim republikama. Prije nego što se vratimo na slabe točke praxis filozofije, koje se pokazuju kao teorijska nedostatnost u pogledu analize suvremenog kapitalizma i institucionalne strukture jugoslavenskog socijalizma, dotaknut ćemo se još jednom internog i eksternog aspekta kroz pokušaj smještanja praxis filozofije u opća kretanja marksističke teorije šezdesetih i sedamdesetih godina kojima je praxis grupacija pridonijela putem izdavačkog rada i organizacijom Korčulanske ljetne škole.

Dosadašnja analiza pokazala je podvojen status filozofije Gaje Petrovića u pogledu politizacije filozofije. Kod Petrovića politizacija je prvenstveno vezana uz ulazak filozofije u političko polje putem kritike staljinizma. Takva je kritika zasigurno imala liberalizirajući, iako teško mjerljiv učinak na jugoslavensko polje kulturne proizvodnje, ali je istovremeno transformirala sam predmet kritike. Kroz razmjerno kratko razdoblje kritika staljinizma pretvorila se, svjesno ili ne, u zamjensku strategiju praxis grupacije s povratnim učinkom udaljavanja od žarišnih točaka jugoslavenskog socijalizma, prije svega pitanja ekonomske liberalizacije i političke decentralizacije. Riječ je o procesima koji se mogu rekonstruirati na razini analize sukoba između različitih frakcija unutar Saveza komunista od pedesetih godina naovamo. Ovdje treba spomenuti da neki ekonomski povjesničari, poput Susan Woodward (1995), lociraju problematični liberalni moment ne samo u liberalnim reformama s početka šezdesetih godina, nego na razini same koncepcije samoupravljanja. Woodward napominje da u temelju samoupravljanja leži klasična liberalna ideja ekonomskog interesa, te da se jugoslavensko samoupravljanje razvilo kao hibrid socijalističkih i liberalnih pretpostavki o ekonomskom ponašanju i ciljevima ekonomskog i političkog života (WOODWARD, 1995: 171). Nadalje, Danijela Dolenec ukazuje, analizirajući rad Josipa Županova, na liberalne tendencije unutar samog jugoslavenskog intelektualnog polja. Županov, naime, upravo u godinama djelovanja praxis grupacije, od 1967. do I969. razvija tezu o radikalnom egalitarizmu, odnosno egalitarnom sindromu djelatnom u jugoslavenskom društvu, koji nije kompatibilan s načelima tržišnog društva i konzekventno onemogućuje jugoslavensku modernizaciju (DOLENEC, 2014). Bez ulaženja u daljnju raspravu o tom pitanju možemo reći da je praxis škola propustila, uslijed logike vlastitog razvoja i pozicije unutar akademskog polja, adresirati ona pitanja koja će se kasnije, osobito nakon dužničke 
krize osamdesetih godina, ispostaviti kao pogubna za jugoslavenski samoupravni socijalizam, ali i kretanje marksističke teorije u postsocijalističkom razdoblju.

\section{Na tragu zapadnog marksizma?}

Kako je na početku napomenuto, "kultiviranje kritike birokratskog aparata socijalističke države” kod Petrovića je vezano uz inzistiranje na teorijskoj ulozi koju filozofija, po njegovom mišljenju, treba imati u raspravi o socijalizmu. On će u tekstu "Filozofija i socijalizam” još jednom potvrditi da "nema socijalizma bez... radikalne i bitne kritike samootuđenog društva i bez rasvjetljavanja mogućnosti razotuđenja” (PETROvić, 1986 B: 381). Ako se prisjetimo kružne logike Petrovićeve argumentacije, to znači da je cijena politizacije filozofije počevši od kritike staljinizma neprestano održavanje njezine utemeljiteljske uloge, njezinog statusa epistemički privilegiranog diskursa koji doslovce utemeljuje "autentično bivstvovanje”.

Ovaj zacrtani odnos akademske, institucionalizirane filozofije i akademskog marksizma odgovara barem u jednom dijelu suvremenim kretanjima marksističke teorije u 20. stoljeću. Prema polemičnoj analizi Perryja Andersona, izdanoj 1976. godine pod naslovom Razmatranja o zapadnom marksizmu, marksističku teoriju od sredine 20. stoljeća obilježava paralelni proces akademske institucionalizacije i premještanja središnjih preokupacija od problema ekonomije i politike na probleme iz domene filozofije. U sadržajnom pogledu, iako "nijedan od protagonista zapadnog marksizma nije tvrdio da je konačni ili glavni cilj historijskog materijalizma teorija znanja”, njihova je zajednička pretpostavka bila da je preliminarna zadaća marksizma razrada i nadopuna Marxove metode, što je posljedično proizvelo mnoštvo priloga unutar korpusa zapadnog marksizma koji su zajedno činili “dugu i zamršenu raspravu o metodi” (ANDERSON 1976: 53). Anderson tretira diskurs zapadnog marksizma, utjelovljen u radovima kao što su Um i revolucija (Marcuse), Marksizam i Hegel (Colleti), Kritika dijalektičkog uma (Sartre), Negativna dijalektika (Adorno), Čitati Kapital (Althusser), kao diskurs drugog reda - koji radi na samom Marxu, a ne na onom na čemu je Marx radio, naime na analizi kapitalističke dinamike. Središnji učinak zapadnog marksizma svodi se na razdvajanje marksističkog teoretiziranja i radničkog pokreta, te na specifičnu teorijsku elaboraciju kooptacije rada i radničkog pokreta, posebno prisutnu u kasnijim radovima Frankfurtske škole, za koju je Sloterdijk u Kritici ciničkoga uma tvrdio da predstavlja samoopoziv 
prosvjetiteljstva i ulazak cinizma kao krive prosvijećene svijesti . U svakom slučaju, praksisovci su do određene mjere uklopljeni u opću struju zapadnog marksizma, zajedno s njegovim specifičnim premještanjima i potrebom da se kroz oslonac na Ekonomsko-filozofske rukopise i Kritiku Hegelove filozofije prava uobliči filozofska dimenzija Marxa. O tome, opet, ne moramo spekulirati budući da o tim utjecajima Petrović eksplicitno piše:

"Vi ste to tačno uočili: iako u svojim snopovima ["Filozofija i revolucija. Dvadeset snopova pitanja”, op. a.] nisam direktno citirao ni Marxa ni Heideggera, ni egzistencijalizam ni strukturalizam, ni bilo kojeg drugog filozofa ni filozofski pravac, imao sam ih sve na neki način u vidu. Iznenađuje kako ste tačnim redoslijedom naveli te glavne mislioce i pravce. U prvom redu tu je 'historija marksizma, zatim dolaze Frankfurtska škola i Heidegger, a za njima hajdegerijanstvo i sve ostalo - sve do suvremenih političkih pokreta." (PETROVIĆ, 1986 B: 95)

S obzirom na navedeno možemo ustvrditi da je projekt refilozofikacije marksizma uvjetovan kako pozicijom praksisovaca u domaćem intelektualnom polju tako i općim tendencijama unutar marksističke teorije koje su se institucionalno i argumentacijski stabilizirale u korpusu zapadnog marksizma. Međutim, usprkos uklopljenosti i vidljivosti na međunarodnoj filozofskoj sceni, ili možda baš zbog toga, praksisovci nisu do kraja svoga grupnog postojanja bili u stanju napraviti potrebne teorijske manevre kako bi neutralizirali vlastite slabe točke. Osim kritike nacionalizma, drugi aspekti jugoslavenskog socijalizma jedva da su ozbiljno dotaknuti. Poput njihovih pandana $u$ zapadnom marksizmu, praksisovci su patili od inhibicije u pogledu suočavanja s temeljnim ekonomskim i političkim pitanjima - a kada su takva pitanja i došla na dnevni red, ona su morala biti prevedena u jezik akademske filozofije, pri čemu je značajan dio problematike, osobito kad je riječ o jugoslavenskom samoupravljanju, ostao izgubljen u prijevodu. Anderson navodi kako su ključna djela zapadnog marksizma napisana u situaciji političke izolacija i očaja: Povijest i klasnu svijest Lukács piše u egzilu nakon pada komune u Mađarskoj I9I9., Gramsci radi na svojim bilježnicama u zatvoru u okolici Barija, Marcuse izdaje Eros i civilizaciju 1954. godine u jeku McCarthyjevog lova na komuniste u Sjedinjenim Državama itd. Nasuprot tome, glavni radovi praksisovaca ipak nisu proizvod političke izolacije i očaja usprkos nezavidnom položaju i pritiscima koje je redakcija časopisa Praxis trpjela, osobito u 
posljednjim godinama izlaženja. Čak i nakon zabrane časopisa pojedini su članovi praxis grupacije bili stalni predmet intelektualne kritike pojedinih visokopozicioniranih ljudi iz Saveza komunista. Tako će primjerice Edvard Kardelj na sljedeći način karakterizirati poziciju praksisovaca:

“Međutim, duboka proturječnost između najamnog položaja inteligencije i njene težnje za održavanjem svog privilegiranog položaja u društvu čini da ideologija ultra-ljevice kao pokreta pati od proturječnosti između ciljeva i rezultata. Ona je u pobuni protiv svih vidova autoritarnog poretka, protiv odnosa vladanja $i$ podčinjavanja, protiv hijerarhije u društvu. No, da bi se sproveli njeni nerealni zahtjevi, potrebna je ogromna moć prinude. Potrebna je velika motka u rukama administrativne sile (u stvari, ponovo države), 'vaspitna diktatura' koja će odmah uvesti novo društvo.” (KARDELJ, 1978: 88)

Ovakva vrsta ciničnog manipuliranja od strane Kardelja omogućena je ne samo njegovom pozicijom moći na vlasti, nego prazninom koju su praksisovci ostavili za sobom u pogledu analize jugoslavenskog socijalizma. Ipak, “neuspjeh” Petrovićeve filozofije prakse ne ogleda se u nemogućnosti da se ponudi stvarna alternativa dominantnoj teoriji i tendencijama jugoslavenskog samoupravljanja. Na razvoj samoupravljanja i jugoslavenskog društva praksisovci su, u svojoj akademskoj ulozi, teško mogli značajno utjecati. U pogledu Petrovića i zagrebačke frakcije praxisa neuspjeh se, ako je takav termin uopće primjeren, očituje prije svega na teorijskoj razini. Tu prije svega mislimo na sumrak marksističke teorije koji je nadošao početkom devedesetih godina. Nestanak marksizma iz javne sfere nije uvjetovan samo usponom nacionalizma, nego je također riječ o aktivnoj evakuaciji s marksističkih pozicija u kontekstu opće prilagodbe novoj situaciji na sveučilištu tokom devedesetih (USP. DOLENEG, DOOLAN I ŽITKO, 2015). Petrovićeva filozofija prakse, a kasnije i njezina izvedenica "mišljenje revolucije”, pokazale su se nedostatnim temeljem za utemeljenje marksističkog istraživačkog programa. Iz marksističke filozofije praxis, čiji su kapaciteti za kritiku političke ekonomije i klasnu analizu do početka devedesetih u potpunosti atrofirali, nisu se neposredno ili u obliku kritičke diskusije razvili novi pravci marksističkih istraživanja. Upravo suprotno, praxis je filozofija postala tokom devedesetih predmet naknadnog uklapanja u korpus hrvatske filozofije, to jest predmet eksplicitnog ili implicitnog osporavanja. Na pozadini filozofske, 
institucionalne i političke povijesti praxis filozofije, pokazuje se da je Gajo Petrović bio u pravu makar u jednom: "Dokle će revolucija stići, to nije stvar samo mišljenja.” (PETROvić, 1986 B: 24) đ

\section{LITERATURA}

Anderson, Perry (1976), Considerations on Western Marxism, London: Verso

Bourdieu, Pierre (1996), The Political Ontology of Martin Heidegger, Cambridge UK: Polity Press

Bourdieu, Pierre (200o), Pascalian Meditations, Stanford CA: Stanford University Press

Dolenec, Danijela (20I4), “Preispitivanje 'egalitarnog sindroma' Josipa Županova”, Politička misao 5I(4), str. 4I-60

Dolenec, Danijela, Doolan, Karin i Žitko, Mislav (20I5), “Plus ça change: Mapping Conversions in the Croatian Academic Field in the Early I99os", u: Universities and Elite Formation in Central, Eastern and South Eastern Europe, Florian Bieber i Harald Heppner, ur. Berlin: Lit-Verlag

Đilas, Milovan (20I0), Nova klasa, Zagreb: Feniks knjiga

Gay, Peter (1999), Weimarska kultura, Zagreb: Konzor

Habermasa, Jürgen (1973), "Marksizam i građansko društvo", u Praxis, 5-6, str. 6oI-6II

Kardelj, Edvard (1978), Pravci razvoja političkog sistema socijalističkog samoupravljanja, Beograd: Izdavači centar "Komunist"

Mikulić, Borislav (20I5a), Nauk neznanja. Retrospekcije o Kangrgi i nasljeđu praxisa, Zagreb: Arkzin

Mikulić, Borislav (20I5b), "Politicum praxisa” (OvDJE: 74-III)

Petrović, Gajo (1965), Filozofija i marksizam, Zagreb, Mladost

Petrović, Gajo (1972), Čemu praxis?, Zagreb: Hrvatsko filozofsko društvo

Petrović, Gajo (1986a), Filozofija prakse, Zagreb: Naprijed

Petrović, Gajo (1986b), Mišljenje revolucije, Zagreb: Naprijed

Petrović, Gajo (1986c), Marx i marksisti, Zagreb: Naprijed

Pippin, Robert (2005), Persistance of Subjectivity: On the Kantian Aftermath, Cambridge UK:

Cambridge University Press

Popov, Nebojša ur. (2004), Sloboda i nasilje, Beograd: Res Publica

Sloterdijk, Peter (1992), Kritika ciničkoga uma, Zagreb: Globus

Sutlić, Vanja (1974), Praksa rada kao znanstvena povijest, Zagreb: Kulturni radnik

Woodward, Susan (1995), Socialist Unemplyment: Political Economy of Yugoslavia 1945-I990, Princeton: Princeton University Press 